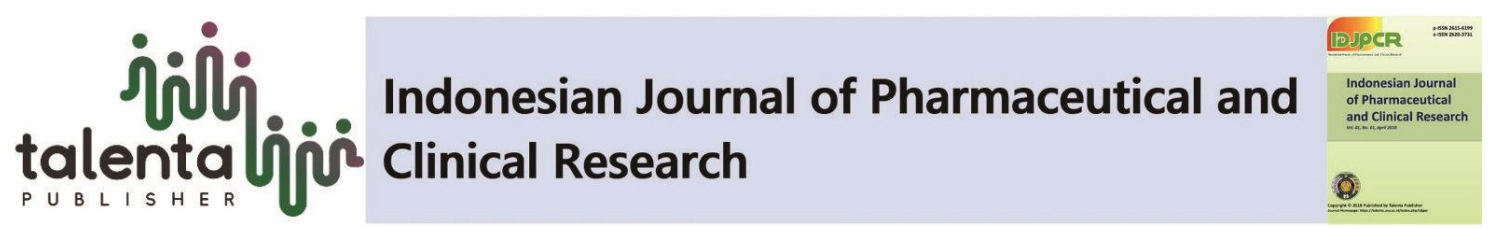

\title{
Antibacterial Activities of Perfume: Combination Flower Magnolia alba, Cananga odorata and Mimusops elengi L, Fixed with Pogostemon cablin Oil
}

\author{
Rosnani Nasution $^{1 *}$, Azalia Izdhihar Azwarl, Hira Helwati ${ }^{1}$, Marianne ${ }^{2}$ \\ ${ }^{1}$ Department of Chemistry, Faculty of Mathematics and Natural Sciences, Universitas Syiah Kuala, Banda \\ Aceh 23111, Indonesia. \\ ${ }^{2}$ Department of Pharmacology, Faculty of Pharmacy, Universitas Sumatera Utara, Medan 20155, \\ Indonesia,
}

\begin{abstract}
The making of perfume from the combination Magnolia alba (M. alba) flower oil, Cananga odorata ( $C$. odorata) and Mimusops elengi L (M. elengi) fixed with Pogostemon cablin oil (P. cablin) have been done. Essential oil of M. alba and C. odorata was distilled by water distillation and extraction essential oil of $M$. elengi flower using nhexane evaporated solvent method. Composition perfume through organoleptic test obtained with a ratio of $4 \% \mathrm{v} / \mathrm{v}, 4 \% \mathrm{v} / \mathrm{v}$, and $2 \% \mathrm{v} / \mathrm{v}$ for each essential oil $M$. alba, C. odorata and $M$. elengi. Antibacterial activity of the perfume and each of the volatile oil was performed by the disc diffusion method. Antibacterial activity test showed that perfumes were able to inhibit the growth of Escherichia coli (E. coli) and Staphylococcus aureus (S. aureus) bacteria, but less active. Antibacterial activity of the perfume was more active against $E$. coli with an inhibitory zone of $8.3 \mathrm{~mm}$ and $39.81 \%$ inhibitory power than $S$. aureus bacterial 7.3 $\mathrm{mm}$ inhibition zone with $37.55 \%$ inhibitory power. Perfumes after storage for one, and two months had better antibacterial activity than before storage with an average inhibitory zone of 11-15 mm and inhibitory power of $50-68,18 \%$.
\end{abstract}

Keywords: Antibacterial; E. coli; C. odorata; M. alba; M. elengi; P. cablin; S. aureus

\begin{abstract}
Abstrak. Pembuatan parfum dari kombinasi minyak bunga Magnolia alba (M. alba), Cananga odorata ( $C$. odorata) dan Mimusops elengi L (M. elengi) yang difiksasi dengan minyak Pogostemon cablin (P. cablin) telah dilakukan. Minyak esensial M. alba dan C. odorata didistilasi dengan destilasi air dan ekstraksi minyak atsiri bunga M. elengi menggunakan metode pelarut n-heksana yang diuapkan. Komposisi parfum melalui uji organoleptik diperoleh dengan rasio 4\% (v/v), 4\% (v/v), dan 2\% (v/v) untuk masingmasing minyak atsiri M. alba, C. odorata dan M. elengi. Aktivitas antibakteri parfum dari masing-masing minyak atsiri dilakukan dengan metode difusi cakram. Uji aktivitas antibakteri menunjukkan bahwa parfum mampu menghambat pertumbuhan bakteri Escherichia coli (E. coli) dan Staphylococcus aureus (S. aureus). Aktivitas antibakteri parfum lebih aktif terhadap E. coli dengan zona hambat 8,3 mm atau daya hambat 39,81\% dibandingkan dengan bakteri $S$. aureus dengan zona hambat 7,3 $\mathrm{mm}$ atau daya hambat 37,55\%. Parfum setelah penyimpanan selama satu dan dua bulan memiliki aktivitas antibakteri yang lebih baik berbanding sebelum penyimpanan, dengan zona hambat ratarata 11-15 mm dan daya hambat 50-68, 18\%.
\end{abstract}

Kata Kunci: Antibakteri; E. coli; C. odorata; M. alba; M. elengi; P. cablin; S. Aureus

Received 25 February 2019 | Revised 06 May 2019 | Accepted 08 May 2019

\footnotetext{
*Corresponding author at: Universitas Syiah Kuala, Banda Aceh, Indonesia.

E-mail address: rosnani@unsyiah.ac.id
} 


\section{Introduction}

Perfume is a substance that has a fragrant and pleasant aroma, can be derived from plants, and can be a combination of various essential oils [1]. The use of essential oils is increasingly being developed in various perfume industries to reduce the negative impact of the use of synthetic substances and to provide aromatherapy effects [2]. However, the use of perfume that can function as an antimicrobial is still very lacking. Essential oils are organic compounds contained in plant parts [3], which contain monoterpenes and sesquiterpene compounds [4]. The distinctive aroma of essential oil has the potential to be developed into a natural scented perfume, the aroma of essential oil in the perfume is tied by adding fixative substances, one of the fixative substances that are often used is patchouli oil (Pogostemon cablin)[5].

Literature studies show that essential oils have the potential to be antimicrobial substances, drugs, pesticides, and cosmetics [6]. Tthe content of monoterpenoid derivatives such as eugenol, thymol, and carvacrol in essential oils is thought to play an active role as an antimicrobial[7].

Some plants that contain essential oils, and are always used as perfumes are $M$. alba flowers, $M$. elengi, C. odorata, which have antimicrobial activities and other medicinal activities.. In addition, M. alba plants also have pharmacological activity as antimicrobial, anti-cancer, anti-plasmodial, antioxidant and anti-depressant [8-9]. M. elengi plants have benefits as antibacterial, antifungal and anticancer [10]. M. elengi essential oil is efficacious as an ingredient of wound salts, boils, and leucorrhoea [11]. Flowers of C. odorata have antibacterial and antifungal activity [12]. The use of C. odorata as an aromatherapy plant effectively reduces depression, high blood pressure and anxiety[13].

Based on the data above, this study carried out, the combination of essential oils of flower from M. alba, M. elengi and C. odorata of which fixed using P. cablin oil, the perfumes hoped inhibits the growth of E. coli and S. aureus of microbes. Organoleptic tests by looking at the fragrance, preference, and sharpness of the scent through.

\section{Methods}

\subsection{Plant Material}

M. alba and C. odorata flowers taken in the village of Meunasah Timue, District Peusangan Selatan, Kab. Bireuen. M. elengi flowers are taken around the Universitas Syiah Kuala campus, Banda Aceh. Samples were taken in January 2017 and determined at the Biology Laboratory Herbarium Department of the Faculty of Mathematics and Natural Sciences, Universitas Syiah Kuala, Banda Aceh. Patchouli oil is obtained directly from the seller of patchouli essential oil in South Aceh. The bioindicator used in this study was the pure culture of E. coli and S. aureus bacteria obtained from the Microbiology Laboratory of the Faculty of Medicine, Universitas Syiah Kuala. 


\subsection{Phytochemical screening}

The method used for testing of phytochemical can be found in: Phytochemical methods, A Guide to Modern Techniques of Plant Analysis [4]

\subsection{Extraction of essential oils}

Extraction of M. alba flower essential oil $(4.7 \mathrm{Kg})$ and $C$. odorata $(2.9 \mathrm{Kg})$ was carried out by the water distillation method. Each fresh flower is sliced and distilled water. Distillation was carried out for 5-8 hours [14]. Extraction of M. elengi flower essential oil was carried out by evaporated solvent extraction method using $n$-hexane solvent.

M. elengi flowers fresh was dried for three days to remove water in flowers, mashed and macerated using $n$-hexane for $3 \times 24$ hours. The filtrate produced is evaporated with a rotary evaporator at a temperature below $35^{\circ} \mathrm{C}$ to obtain concrete essential oil.

\subsection{Refractive index}

Determination of the refractive index of each M. alba, M. elengi, and C. odorata essential oil of flowers was carried out with a refractometer [15].

\subsection{The making of perfume}

Perfume making is made with a combination of three essential oils based on organoleptic tests. Organoleptic tests were carried out by measuring the subjective attitude of respondents based on organoleptic characteristics. The data provided is in the form of a personal response questionnaire about the level of fragrance, favorite and sharpness of a combination of perfume. This test uses respondents and there is no comparison test material. The test subjects use a scale of 1-5 [16]. Respondents consisted of 40 people with age criteria (20-25 years). The form of the organoleptic test form can be seen in Table 1 .

Table 1. Forms of organoleptic combinations of three essential oils

\begin{tabular}{cccc}
\hline No. & Fragrance Level & $\begin{array}{c}\text { Scale Favorite } \\
\text { Level }\end{array}$ & Sharpness Level \\
\hline 1 & Very fragrant & Very like & Very sharp \\
2 & Fragrant & Likes & Sharpness \\
3 & A little fragrant & Little likes & A little sharp \\
4 & Not fragrant & Don't like & Not sharp \\
5 & Very not fragrant & Very dislike & Very not sharp \\
\hline
\end{tabular}

The combination of essential oils was carried out with variations in composition by looking at the effect of one variable on the other variables based on the percentage of use of each essential oil. Then the optimum composition test for $M$. Alba oil was carried out, tested the optimum 
composition for essential oils of $C$. odorata, tested the optimum composition for M. Elengi essential oil, so that the optimum composition of each essential oil (in percent) was then used as a constituent of perfume which is found in Table 2 .

Table 2. The composition of essential oils making up perfume (combination of three essential oils)

\begin{tabular}{ccccc}
\hline \multicolumn{5}{c}{ Composition (\% b/v) } \\
\hline M. alba & C. odorata & M. elengi & P. cablin & Alcohol \\
4 & 4 & 2 & 5 & make up to 100 \\
\hline
\end{tabular}

\subsection{Antibacterial activity test}

Antibacterial activity of perfume and each essential oil against E. coli and S. aureus were carried out by disc diffusion method. Antibacterial testing is carried out by placing disc paper that has been filled with perfume and essential oil on the test media which has been inoculated with $E$. coli and S. aureus bacteria respectively. The positive control of the antibacterial test was gentamicin, while the alcohol and $n$-hekasana were negative controls for each test. Incubation is carried out for 18 hours to see the inhibitory zone against antibacterial. The inhibition zone is measured using a ruler in millimeters [17]

\section{Result And Discussion}

\subsection{Essential oil extraction}

Fresh flower distillation of $M$. alba $(4.7 \mathrm{Kg})$ and C. odorata $(2.9 \mathrm{Kg})$ was carried out for 4-8 hours [14]. The results obtained from M. alba flower was $5.98 \mathrm{~mL}$ of essential oil with a yield of $0.1 \%$ (v / b), and from C. odorata flowers obtained $8.07 \mathrm{~mL}$ of essential oil with a yield of $0.2 \%$ (v / b). The extraction of $M$. elengi flower essential oil using the $n$-hexane vaporizing solvent method yielded a yield of $0.714 \%$ (b / b).

The results of essential oils obtained from the three flowers above are tested their phytochemical, and the refractive index is tested.

Phytochemical test results on fresh samples and essential oils of M. elengi showed terpenoids. The terpenoid test was carried out using the Liebermann-Burchard reagent, this test showed positive results with observations of the formation of a red color[4]

\subsection{Refractive index}

The test results of the refractive index values of the essential oils of $C$. odorata, M. alba, and $M$. elengi are shown in Table 3. 
Table 3. Essential oil refraction index test

\begin{tabular}{lc}
\hline Essential oil & Refraction index $(\mathrm{nD})$ \\
\hline C. odorata & 1,483 \\
M. alba & 1,455 \\
M. elengi & 1,488 \\
\hline
\end{tabular}

The three essential oils above meet the value of the refractive index of essential oils in general. There are several essential oils that already have quality standards (SNI), one of which is Cananga oil or Essential oil of $C$. odorata. Based on SNI quality standards the refractive index of $C$. odorata oil ranges between (1493-1503).

\subsection{The Perfume Organoleptic}

Organoleptic testing is carried out including the test of fragrance level, aroma preference, and sharpness. This aims to determine the optimum composition of each constituent oil as a perfume. The optimum composition of each essential oil was determined from the percentage level of the panelists with the criteria of fragrant, like and have a non-sharp aroma. Analysis of the panelists response to the variation in the concentration of essential oil of M. alba is shown in Figure 1. Analysis of the panelists response to the concentration of $C$. odorata essential oil is shown in Figure 2 and analysis of the response of panelists to the concentration of M. elengi essential oil is shown in Figure 3.

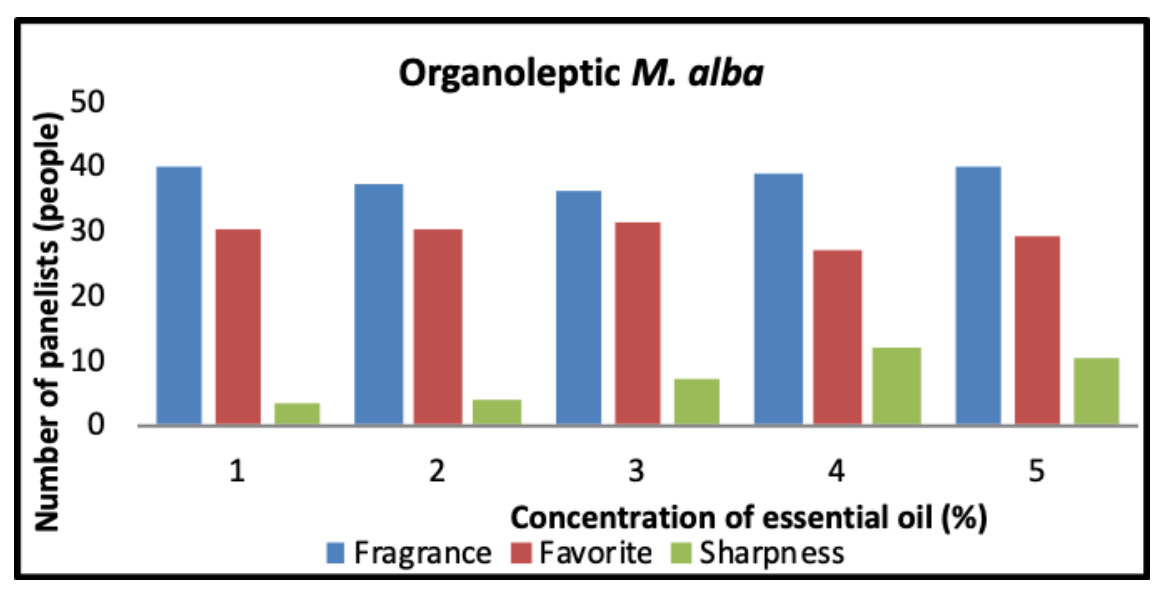

Figure 1. Respond from panelists to variations in the concentration of essential oils $M$. alba flower 


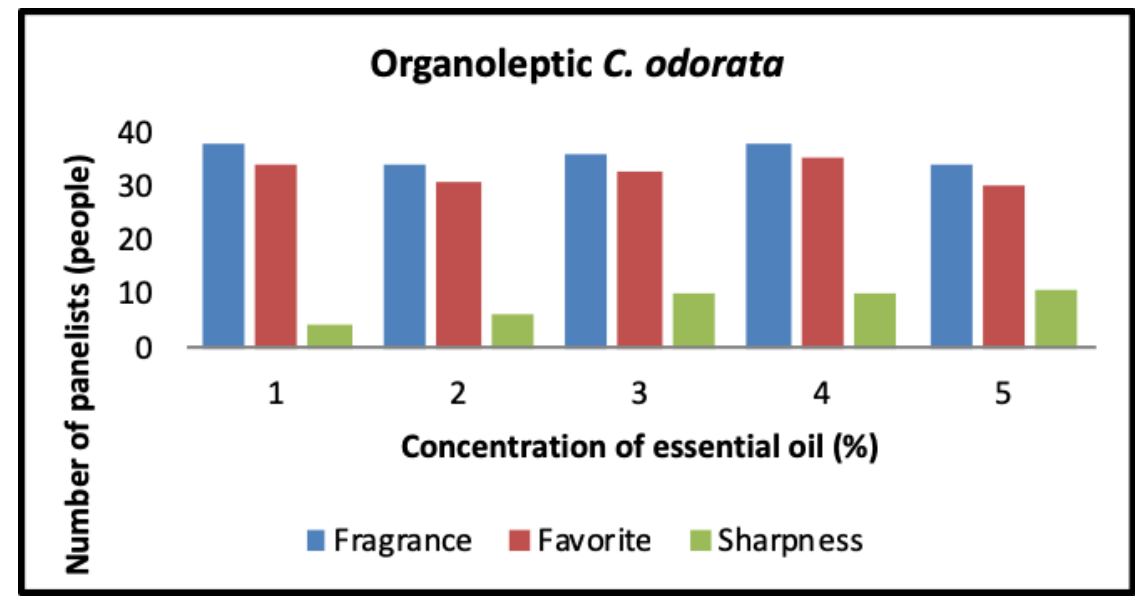

Figure 2. Respond from Panelists to variations in the concentration of essential oils $C$. odorata flower

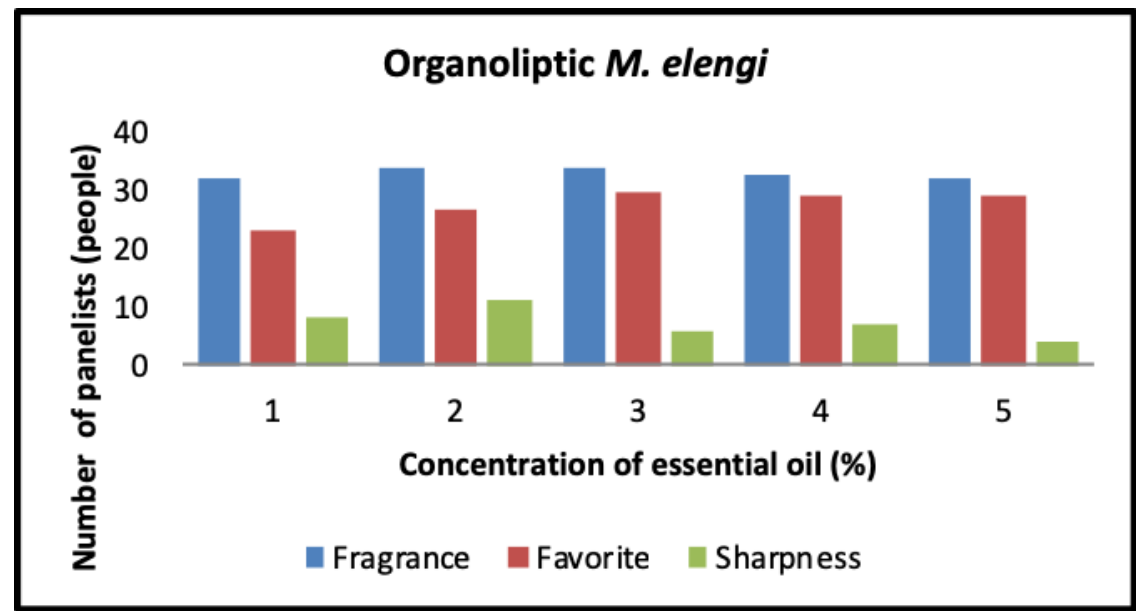

Figure 3. Respond from panelists to variations in the concentration of essential oils M. elengi flower

Based on figures 1, 2, and 3 above, it shows that the optimum composition is $4 \%$ (v / v ) essential oil of $M$. alba flower, $4 \%$ (v/ v) essential oil C. odorata and 2\% (v/b ) essential oil concrete $M$. elengi . The results of the organoleptic data statistic analysis were performed using the T-test by looking at the best concentration ratio. Perfume with the optimum composition of organoleptic test results (the most preferred by panelists) was tested for antibacterial activity, against $S$. aureus and E. coli bacteria.

\subsection{Antibacterial Activity}

The results of the antibacterial activity test of each essential oil, a combination of essential oils and essential oils in alcohol are shown in Table 4. 
Table 4. Inhibition zones ( $\mathrm{mm}$ ) of each essential oil, perfume (combination of three essential oils), each essential oil with alcohol, against $S$. aureus and E. coli bacteria

\begin{tabular}{lcc}
\hline \multirow{2}{*}{ Essential oil } & \multicolumn{2}{c}{ Inhibitory zone $(\mathrm{mm})$} \\
\cline { 2 - 3 } & S. aureus & E. coli \\
\hline P. cablin & 12,6 & 12,6 \\
C. odorata & 13,6 & 11,6 \\
M. elengi & 6 & 7,3 \\
M. alba & 13 & 13 \\
Essential oils with the addition of alcohol & & \\
$2 \%$ M. elengi & 8,6 & 8 \\
$4 \%$ C. odorata & 8,6 & 8,3 \\
$4 \%$ M. alba & 8,3 & 7,6 \\
5\% P. cablin & 10,3 & 11 \\
Combination of essential oils & & \\
P. cablin + C. odorata + M.alba + M. elengi + alcohol & 8,6 & 8,3 \\
P. cablin + C. odorata + M.alba + alcohol & 13 & 11 \\
P. cablin + M.alba + M. elengi + alcohol & 7,6 & 8 \\
P. cablin + C. odorata + M. elengi + alcohol & 10 & 8,6 \\
\hline Key: disc diam $(6$ m $)$
\end{tabular}

Key: disc diameter $(6 \mathrm{~mm})$

Based on data on the diameter of the inhibition zone $(\mathrm{mm})$ in Table 4 above, it can be seen that each essential oil and perfume can inhibit the growth of $S$. aureus and E. coli bacteria.

$C$. odorata essential oil was able to inhibit the best growth of $S$. aureus bacteria with an inhibition zone of $13.5 \mathrm{~mm}$ and obtained a percentage of activity of $59.13 \%$, this value was said to actively inhibit the growth of S. aureus bacteria. This is in line with the research conducted [18], showed that essential oil of $C$. odorata was able to inhibit bacterial growth with an inhibition zone of $12-$ $24 \mathrm{~mm}$.

M. alba essential oil has the best activity to inhibit the growth of E. coli bacteria with an inhibition zone of $13 \mathrm{~mm}$ and a percentage of activeness of $63.10 \%$ so that it can be said that $M$. alba essential oil actively inhibits the growth of $E$. coli bacteria. This is in line with the results of a study conducted [18] proved that M. alba essential oil was able to inhibit the growth of Grampositive and Gram-negative bacteria with an average inhibition zone of 11-17 $\mathrm{mm}$.

The antibacterial activity of M.elengi essential oil was able to inhibit the growth of $S$. aureus bacteria with an inhibitory zone of $6 \mathrm{~mm}$, while the inhibition zone of $E$. coli bacteria was 7.3 $\mathrm{mm}$. When compared with the inhibitory activity of the growth of $S$. aureus essential oil, $\quad M$. elengi is more able to inhibit the growth of E. coli bacteria which is a Gram-negative bacterium, this result is in line with that reported [19] that M. elengi flower essential oil is only active against Gram-negative bacteria. 
The antibacterial activity of each essential oil added to alcohol was obtained by a relatively small inhibition zone compared to the pure essential oil activity, except for M. elengi essential oil with a concentration of $2 \%$ having better activity than the pure concrete essential oil. Patchouli essential oil with a concentration of $5 \%$ decreased slightly compared to pure oil.

Perfume (a combination of three flower essential oils namely M. alba, C .odorata, and M. Elengi) which were fixed with $P$. cablin oil was able to inhibit the growth of $S$. aureus bacteria with an inhibitory zone of $8.6 \mathrm{~mm}$ with a percentage of activity of $39.81 \%$. Based on the percent value of activity obtained, it can be said that perfume which is fixed with $P$. cablin oil is less active to inhibit the growth of $S$. aureus bacteria. The test results of perfume activity on the growth of $E$. coli bacteria obtained an inhibition zone of $8.3 \mathrm{~mm}$ with a percentage of activity of $37.55 \%$. Perfume activity that is less active against these bacteria, is thought to be due to a reaction between the active groups present in each essential oil so as to reduce the activity of a compound. In addition, it is also suspected that the effect of the irregularity of M. elengi essential oil can influence antibacterial activity.

According to the literature, $C$. odorata essential oil contains caryophyllene (36.44\%) and linalool (5.97\%) compounds which are active as antibacterial [20] and in M. alba flower essential oil there is linalool (85.78\%) and caryophyllene (0.92\%) (Punjee et al., 2009). [14]

The antibacterial mechanism of linalool and caryophyllene is the same, by damaging the bacterial cytoplasmic membrane and coagulating cell components [21]

Antibacterial activity is also carried out on perfume after experiencing a storage period of one and two months. Perfume data with the effect of storage period are shown in (Table 5).

Table 5. The zone of inhibition ( $\mathrm{mm}$ ) of perfume after storage of one and two months

\begin{tabular}{lcc}
\hline \multirow{2}{*}{ Composition } & \multicolumn{2}{c}{ Inhibitory zone $(\mathrm{mm})$} \\
\cline { 2 - 3 } & S.aureus & E.coli \\
\hline Alcohol & 8 & 8,5 \\
$n$-hexane & - & - \\
One month storage perfume & 11 & 11,5 \\
Two months of storage perfume & 13,5 & 15 \\
Gentamicin $10 \mu \mathrm{g} / \mathrm{mL}$ & 22 & 22 \\
\hline
\end{tabular}

Key: disc diameter $(6 \mathrm{~mm})$

Inhibitory zone against E. coli and S. aureus are shown in Figure 4. 


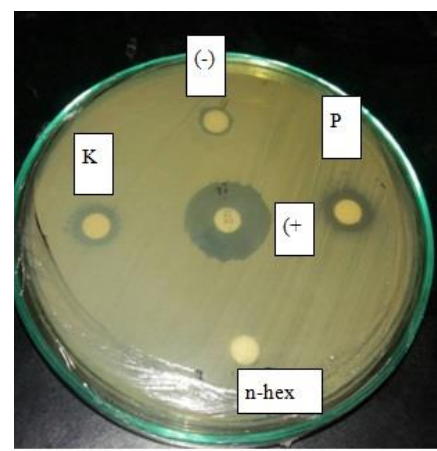

(a)

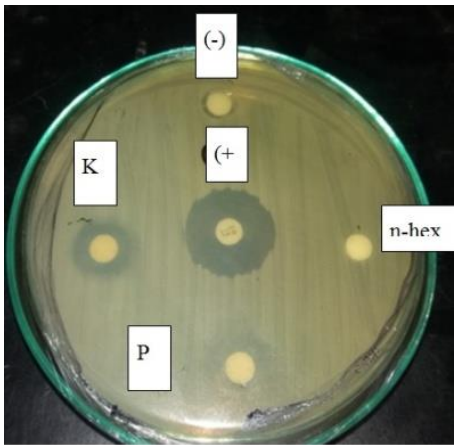

(b)

Figure 4 a. Perfume inhibition zone with storage time variation for $E$. coli bacteria; b. Perfume inhibition zone with storage time variation for $S$. aureus bacteria

The perfume storage period carried out in this study was able to influence antibacterial activity. This is evidenced by a better perfume inhibition zone and a higher percentage of resistance after storage compared to the inhibition zone before storage. After one month of storage, the inhibition zone of perfume for $S$. aureus bacteria was $11 \mathrm{~mm}$ and after storage for two months, an inhibition zone of $13.5 \mathrm{~mm}$ was obtained when compared to the positive control inhibitory zone of $22 \mathrm{~mm}$, the percentage of activity was $50 \%$ for one month storage period, and $61,36 \%$ for two months storage, this value can be said to actively inhibit the growth of $S$. aureus bacteria

The increase in the inhibition zone of perfume was also obtained in antibacterial activity against E. coli bacteria with an inhibition zone of $11.5 \mathrm{~mm}$ for one-month storage and $15 \mathrm{~mm}$ for two months of storage. Compared to the positive control of $22 \mathrm{~mm}$, the percent of activity was $52.27 \%$ for one-month storage and $68.18 \%$ for storage for two months. The percent value of activity obtained is said to actively inhibit the growth of E. coli bacteria. Increased activeness of perfume after storage is suspected during the storage period of each active component able to combine so as to form a synergistic activity in inhibiting the growth of the two test bacteria in addition to the influence of essential oil of $P$. cablin after one month can increase the activity of perfume. However, this research needs to be carried out further. In general, essential oils and perfumes combined with essential oils of $M$. alba, C. odorata, and M. elengi are broad-spectrum antibacterial substances. Because it can inhibit bacterial growth from gram positive and gram negative

The monoterpenes group in essential oil acts as an antibacterial which reacts with porin (transmembrane protein) in the outer membrane of the bacterial cell wall, forming a strong polymeric bond that causes damage to the porin. When the porin has been damaged it will reduce 
the permeability of the bacterial cell wall which will cause bacterial cells to lack nutrients, so that bacterial growth is inhibited or dies [22]. In addition, essential oils that are active as antibacterial generally contain groups $(-\mathrm{OH})$ and carbonyl. Bacteriostatic activities of each essential oil and perfume are generally more able to inhibit the growth of $S$. aureus bacteria than E. coli bacteria. this is because the $S$. aureus bacteria are gram-positive bacteria that have a simpler composition of cell walls compared to E. coli bacteria which are gram-negative bacteria. [23], reported that gram-negative bacteria had a higher lipid composition compared to gram-positive bacteria. Generally, gram-negative bacteria produce mucus as a form of self-defense from chemical compounds that harm it. The outer membrane of gram-negative bacteria acts as a barrier to the entry of compounds that are not needed by cells, such as bacteriocins, enzymes, and compounds that are hydrophobic [24]. Antimicrobial compounds work by being able to penetrate lipopolysaccharides (LPS) from the cell wall. Hydrophilic molecules are easier to pass through LPS compared to hydrophobic ones. Gram- positive bacteria do not have LPS, so nothing prevents the entry of antibacterial substances and molecules of antimicrobial compounds that are hydrophilic and hydrophobic (such as essential oils) can diffuse into cells easily [25].

\section{Conclusion}

Based on the results of research that has been carried out, it can be concluded that the test for antibacterial perfume activity (a combination of M. alba essential oil, C. odorata, and M. elengi) which is fixed with $P$. cablin oil capable of inhibiting the growth of Gram-negative and Grampositive bacteria with an inhibition zone of $8.3-8.6 \mathrm{~mm}$ with a percentage of activity (inhibitory power) of 39.71-38.56\%. The period of storage of perfume (in this study) can affect antibacterial activity, after one month of storage, the inhibition zone of perfume for S. aureus bacteria was 11 $\mathrm{mm}$ and after storage for two months for S. aureus bacteria, an inhibition zone of $13.5 \mathrm{~mm}$, percentage of activity (inhibitory power) was 50\%, and 61, 36\% (compared to Positive control), while for E. coli bacteria was $52.27 \%$ for one-month storage and $61.36 \%$ for two month storage.

\section{REFERENCES}

[1] Webster. M, "Definition Of Perfume", 2017. [Online]. Available : https://www.merriam-webster.com/dictionary/perfume. [Accessed: July. 31 ${ }^{\text {st }}$, 2017].

[2] Aldo, "Penetapan Kadar Benzaldehid pada Sampel Parfum "X" dari 3666 Toko Parfum di Wilayah Surabaya Selatan," Jurnal Ilmiah Mahasiswa, no. 4, pp. 1-11. 2015.

[3] N.S. Rupilu, Y.F. Lamapaha, Potensi Lengkuas Sebagai Antimikroba (Studi In Vitro pada Gram Negatif). Universitas Negeri Malang, Malang: 2008.

[4] Harborne. J.B. Phytochemical Methods: A Guide to Modern Techniques of Plant Analysis, 3rd Edn., Chapman and Hall, London, p.302, 1998.

[5] I. Mustika dan I. Nuryani, "Strategi Pengendalian Nematoda Parasit pada Tumbuhan Nilam," Jurnal Litbang Pertanian XXV, vol. 4, no. 1, pp.7-15, 2006.

[6] S.Y. Hartati, "Prospek Pengembangan Minyak Atsiri Sebagai Pestisida Nabati", Jurnal Perspektif, Vol. 11, No 1, pp.45-58, 2012. 
[7] M.B. Isman, "Plant Essential Oils For Pets and Disease Management", Crop Protection, Vol. 19, No. 8, pp.603-608, 2000.

[8] S.W. Lee, W. Wee, Y.Y.F Siong, D.F. Syamsunir, "Characeristic of Antimicrobial, Antoxidant, Anticancer Property and Chemical Composition of Michelia alba Seeds and Flower Extract", Stamford Journal of Pharmaceutical Sciences, 2014.

[9] H. Tan-li, H. Ming-wu, H. Liang-chen, C. Ming-liu, and C. Yi-chen, "The Pharmacological Activities of (-) - Anonaine" Molecules Journal, Vol. 18, pp.82578263,2013

[10] M.S Baliga, R.J Pai, H.P Bhat, P.L Paliatty, R. Boloor, "Chemistry and Medicinal Properties of The Bakul (Mimusops elengi Linn) : A Review," Food Research Internasional, Vol. 44, Issue. 7, pp.1823-1829, 2011.

[11] M. Roqaiya, W. Begum, S.F. Majeedi and A.Sayed, "A Review on Traditional Uses and phytochemical Properties of Mimusops elengi Linn”, International Journal of Herbal Medicine, Vol. 2, No. 6, pp.20-23, 2015.

[12] N. Zaine, Volatile Compounds and Biological of extract of Curanga odorataand It's petal - Derived Cells, University Putra Malaysia, Malaysia, 2009.

[13] L.T Tan, L.H. Lee, W.F. Yin, Ck. Chan, H. Abdul Kadir, K.G Chan, B.H. Goh, "Traditionl Uses, Phytochemistry and Bioactivities of Cananga odorata (Ylang-ylang)", Hindawi Publishing Corporation, Evidence-Based Complementary and Alternative Medicine, Vol. 2015, Article ID: 896314.

[14] P. Punjee, U. Dilokkunanant, U. Sukatta and S. Vajrodaya, "Scented Extracts and Essential Oil Extraction from Michelia alba D.C", Kasetart journal (Nat-Sci), Vol. 43, pp.197-203, 2009.

[15] F.P Iswara, D. Rubiyano dan T.S julianto, "Anlisis Senyawa Berbahaya dalam Parfum dengan Kromatografi Gas-Spektrofotometri Massa Berdasarkan Material Safety Data Sheet (MSDS)", Indo Journal of Pharmaceutical Research, Vol. 1, Issue 2, pp.18-27, 2014.

[16] Indonesia, Direktorat Pendidikan Dasar dan Menengah Kejuruan, Departemen Pendidikan Nasional, "Menguji Kesukaan secara Organoleptik", Jakarta : 2003.[Online]. Available : http://psbtik.smkn1 cms.net/pertanian/agroindustri/ agroindustri_non_pangan/menguji_kesukaan_secara_organoleptik.pdf

[17] B.W Lay, Analisis Mikrobiologi di Laboratorium, Raja Grafindo, Jakarta, 1994.

[18] K.S. Sree, M. Anudeep, Ch. Bhaskar, "Screening of Antimicrobial Activity of Flower Extracts on Human Bacteria Pathogens", Journal of Pharmacognosy and Phytochemistry, Vol. 3, No. 6, pp.153-156, 2015.

[19] A. Faheem, C.K. Wong, I.M Eldeen, M.Z. Asmawi, H. Osman, "Volatile and Bioactivities of Mimusops elengi Linn Flowers", Latin American Journal of Pharmacy, Vol. 31, No. 2, pp.331-335, 2012.

[20] R. Pujiarti, T.B. Widowati, K. Kasmudjo, S. Sunarta, "Kualitas, Komposisi Kimia dan Aktivitas Antioksidan Minyak Kenanga Cananga odorata", Journal of Forest Science, Vol. 9, No. 1, 2015.

[21] S. Burt, "Essentils oils : Their Antibacterial Properties and Potential Applications in foods", International Journal of Food Microbiology, Vol. 94, Issue. 3, pp 223-253, 2004.

[22] Cowan, "Plant Products as Antimicrobial Agents", Clinical Microbiology Review, Vol. 12, No. 4, pp.564-582, 1999.

[23] E. Jawetz, J.L Melnick and E.A Adelberg, Mikrobiologi Kedokteran, Salemba Medika, Jakarta, 2001.

[24] P. M Davidson, J.N Sofos and A.L Branen, Antimicrobial in Food, $3^{\text {rd }}$ edition., Taylor and Francis Group, London, 2005.

[25] M. Oussalah, S. Callet, L, Saucier and M. Lacroix, "Antimicrobial Effects of Selected Plant Essential Oils on the Growth of a Pseudomonas putida strain Isolated from Meat,"Meat Science, Vol. 73, Issue. 2, pp 236-244, 2006. 